\title{
Could a college merger close the transatlantic gap?
}

\author{
Why UCL, home of Britain's most-cited scientists, should merge with third-place Imperial.
}

Sir - In your Opinion article (Nature 419, $763 ; 2002$ ) about the benefits of a merger between Imperial College and University College London (UCL), you voice concern that these two London colleges will dominate the UK research scene, and you comment that this situation does not happen in the United States. Similar concerns led a group of UK academics and students to vociferously oppose the move, resulting in newspaper reports that the merger has been postponed. I contend that this largely London-based community will come, in time, to be viewed as dangerously parochial. It is precisely the international context, which your Opinion article alluded to, that renders the UCL-Imperial merger so imperative right now, if Europe is to remain academically competitive with the United States (see, for example, Wilhelm Krull's Commentary, Nature 419, 249-250; 2002)

According to the ISI (www.isihighlycited. com) list of the world's 1,200 most cited scientists, the gap between the United States and the rest of the world is widening at an alarming rate. Only about 80 of those scientists are in the United Kingdom. In microbiology, for example, eight of the world's leading scientists are at Harvard Medical School, 71 elsewhere in the United States, and only six in the United Kingdom. Nevertheless, some UK universities do attract clusters of the world's top scientists. Top of the list is UCL with 12, Cambridge is second with 10 and Imperial is third with six. Oxford has only three.

A merger between Imperial and UCL would allow the creation of an institution that for the first time could have the clout to shake up the UK scene. It might allow universities to break free from the constraints of uniform pay, and ensure that academics here are at last rewarded in ways that will stop them bailing out to the United States and elsewhere.

Over and over again, reports about higher education in the UK national press imply that there are only two institutions that can nurture talent: Oxford and Cambridge. This myopia is very damaging, particularly as it limits the interest of overseas students and academics in UK-based research.

The ISI list indicates that there is a lag in public understanding of who really is at the very top of UK higher education, which Imperial and UCL's proposed merger tackled head-on. The publicity surrounding their proposal has already done much to restore the reputations of both institutions to their rightful place.

The way to bring this issue to public and international attention with the urgency it deserves is to merge universities, producing institutions tremendous enough to demand an entry into the academic 'World Series', and to show that the tournament doesn't just belong in the United States. Raj Persaud

Alumni Society, University College London, Gower Street, London WC1E 6BT, UK

\section{Unforeseen growth of academic astrology}

Sir - I was appalled when I read a report in Nature last year about proposals by the Indian government to encourage universities to teach astrology (Nature 411, 227; 2001), but never thought that anything similar might occur in the West. It now seems that I was mistaken.

A British organization called the Sophia Project declares on its website (www.sophia-project.org.uk) that its goal is "to advance the scholarly study of astrology and cultural astronomy in British institutions of higher education". The Sophia Project currently funds four principal initiatives at British universities (the Warburg Institute at London; Southampton; Kent at Canterbury; and Bath Spa University College). The initiative at the University of Southampton, which is called the Research Group for the Critical Study of Astrology, states on its website (www.rgcsa.org) that its disciplinary scope includes "research in the field of psychology (ably begun by the late Hans Eysenck) on the links, if any, between personality and more complex indicators of supposed planetary influence".

One research project being funded in this way is a study of the possible impact of the planets on fertility and childbirth; another is the possible correlation of birth date and prostitution; and another is the effect of Jupiter on alcoholics.

The Sophia Project, which funds the Southampton group, is funded by a private benefactor, but the participation of any institution of higher education surely entails the use of at least some public money in support of bogus research. Dylan Evans

Department of Mechanical Engineering, University of Bath, Bath BA2 7AY, UK

\section{DNA database could end problem of identity fraud}

Sir - Although no system is perfect, your correspondents (Nature 419, 247-248; 2002) seem to have missed the point about DNA testing, made by R. Williamson and R. Duncan in their Commentary "DNA testing for all" (Nature 418, 585-586; 2002). First, it is the most reliable method of identification. Second, DNA evidence has brought about more acquittals on appeal after false convictions than convictions of the innocent. Third, identity theft and identity fraud are bigger problems for most citizens than a theoretical risk of false conviction or state coercion (for which a DNA database is hardly a necessity), not to mention the issues of preventing or dealing with mass fatalities like those of 11 September 2001.

Forensic databases are arguably discriminatory in that only suspects and those previously convicted are in danger of falling victim to a false match. A universal database would be equally fair or unfair to everyone.

The UK government introduced a requirement to register births, deaths and marriages in 1837 . To implement a twentyfirst century register backed by DNA is simply modernization.

Martin Evison

Forensic Pathology, Sheffield University Medicolegal Centre, Sheffield S3 7ES, UK

\section{Caption confusion}

Sir - The photograph illustrating your News story "Suspicions intensify over elusive European Academy of Sciences" (Nature 419, 855; 2002) is not of Brussels but of another Belgian city: Bruges. This city, called "the Venice of the North" because of its many canals, is well known to tourists. I know nothing about the organization discussed in your article, but what does exist in Bruges is the European College (www.coleurop.be), a postgraduate institute of European studies. Jean-Paul Schiepers J.P.S@skynet.be,Belgium

The caption supplied by the photo library to accompany this picture identified the city as Brussels. Nature regrets this error, which was pointed out by several readers - Editor, Correspondence 